\title{
OPEN Author Correction: Whole genome sequencing reveals the impact of recent artificial selection on red sea bream reared in fish farms
}

\author{
Bo-Hye Nam, DongAhn Yoo (iD, Young-Ok Kim, Jung Youn Park, Younhee Shin, Ga-hee Shin, \\ Chan-Il Park, Heebal Kim \& Woori Kwak \\ Correction to: Scientific Reports https://doi.org/10.1038/s41598-019-42988-z, published online 24 April 2019 \\ In this Article, the Data availability section was omitted from the Additional Information section:
}

Availability of Data in NCBI Database: The DNA read data from the fish samples were submitted to the NCBI database under BioProject ID of PRJNA578498.

\begin{abstract}
(c) (i) Open Access This article is licensed under a Creative Commons Attribution 4.0 International (c) License, which permits use, sharing, adaptation, distribution and reproduction in any medium or format, as long as you give appropriate credit to the original author(s) and the source, provide a link to the Creative Commons license, and indicate if changes were made. The images or other third party material in this article are included in the article's Creative Commons license, unless indicated otherwise in a credit line to the material. If material is not included in the article's Creative Commons license and your intended use is not permitted by statutory regulation or exceeds the permitted use, you will need to obtain permission directly from the copyright holder. To view a copy of this license, visit http://creativecommons.org/licenses/by/4.0/.
\end{abstract}

(C) The Author(s) 2020 